\title{
The Effectiveness of cognitive therapy based on mindfulness on positive affect, psychological flexibility and mind-awareness components of people With depression symptoms
}

\author{
Mitra Goudarzi ${ }^{1}$, Neda Ghasemi ${ }^{2}$, Fazlollah Mirderikvand $^{3}$, Simin GholamreZaei $^{4}$ \\ 1- Ph.D. student, Psychology Department, Lorestan University, Khoram Abad, Iran. ORCID: 0000-0003-2914- \\ $895 \mathrm{x}$ \\ 2- Ph.D. student, Psychology Department, Lorestan University, Khoram Abad, Iran. ORCID: 0000-0002-5863- \\ 8133 \\ 3- Associate Professor, Psychology Department, Lorestan University, Khoram Abad, Iran. ORCID: 0000-0002- \\ 6994-024x E-mail: mirfazlolah@yahoo.com \\ 4- Assistant professor, Psychology Department, Lorestan University, Khoram Abad, Iran. ORCID: 0000-0002- \\ 0489-3155
}

Received: 01/09/2018

Accepted: 19/11/2018

\begin{abstract}
Introduction: Depression is recognized as one of the most common disabling and recurrent disorders with changes in emotional, cognitive, and neurobiological functions over a twoweekperiod.
\end{abstract}

Aim: The purpose of this study was to determine the effectiveness of cognitive therapy based on mindfulness on positive affect, psychological flexibility and mind-awareness components of people with depression symptoms.

Method: The research method was semi-experimental with control and experimental group as pre-test and post-test. 30 students with depression symptoms were selected using purposeful sampling. They were randomly assigned to control and experimental groups. The experimental group received 8 sessions of cognitive therapy based on mind-awareness while the control group received no training at al. Beck Depression Inventory, Acceptance and Practice Questionnaire-II (AAQ-II), Positive and Negative Affect Scale, and Five-Point Mindfulness Questionnaire were used for data collection.

Results: The results showed that cognitive therapy based on Mindfulness increases the scores of the experimental group in the positive affection, psychological flexibility and component of mindfulness and decreased levels of negative affect.

Conclusion: cognitive therapy based on Mindfulness is effective to enhance positive affec, psychological flexibility and mindfulness components.

Keywords: Cognitive therapy based on mindfulness, Positive affect, Psychological flexibility, Mindfulness components, Depression 


\title{
اثربخشى شناخت درمانى مبتنى بر ذهن آحاهى بر عاطفه مثبت و منفى، انعطاف يذيرى

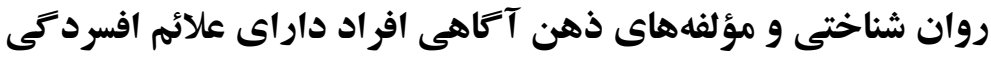

\author{
ميترا كودرزى '، نداقاسمى'، فضل اله ميردريكوندِّ، سيمين غلامرضايى' \\ ا. دانشجوى دكترى، گروه روان شناسى، دانشكاه لرستان، خرم آباد، ايران.

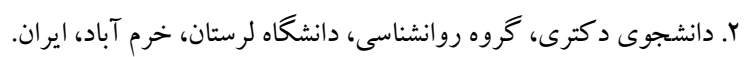

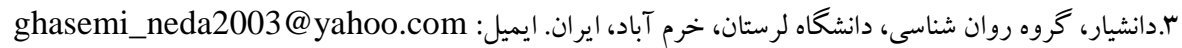

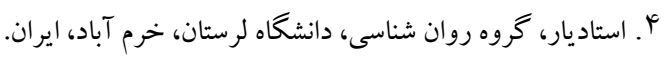

مقدمه: افسردكى به عنوان يكى از شايعترين اختلالات ناتوان ساز و عودكننده با تغييرات در عاطفه، شناخت و كاركردهاى

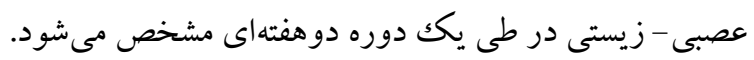
هدف: يُزوهش حاضر با هدف بررسى اثر بخشى شناخت درمانى مبتنى بر ذهن آكاهى بر عاطفه مثبت، انعطافيذيرى

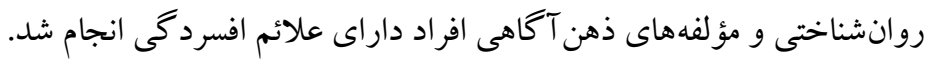

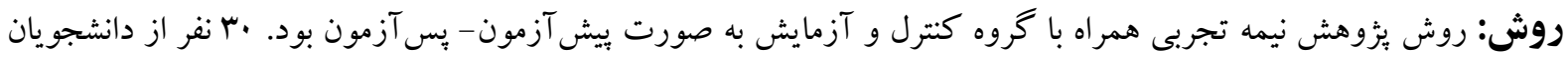

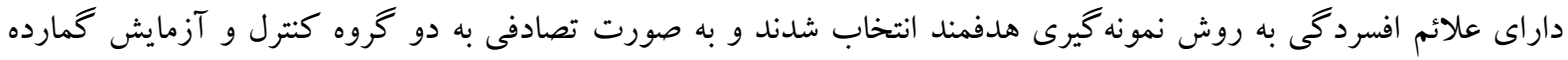

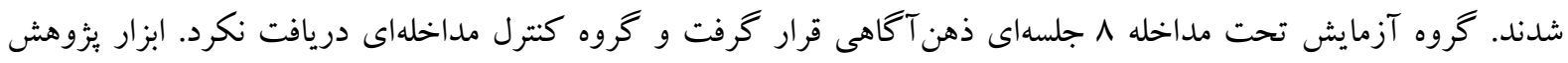

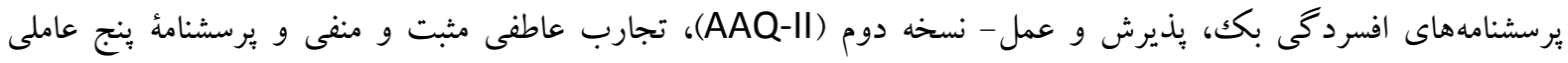
ذهن Tكاهى بود.

يافتها: نتايج تحليل كواريانس نشان داد كه آموزش ذهن آكاهى تأثير معنادارى بر عاطفه مثبت و منفى، انعطاف بذيرى روان شناختى و مهارت هاى ذهن آكاهى دارد. نتيجه كيرى: درمان ذهن آكاهى جهت افزايش عاطفه مثبت، انعطاف بذيرى دهى روان شناختى و مهارت هاى ذهن آكاهى افراد افسرده از ازثربخى لازم برخوردار است. دمان. كليد وازهها: شناخت درمانى مبتنى بر ذهن آكاهى، عاطفه مثبت، عاطفه منفى، انعطاف بذّيرى روانشناختى، مهارتهاى ذهن

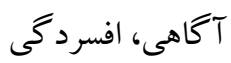


ابو القاسمى و احمدى، اجوسا). عواطف منفى از جمله

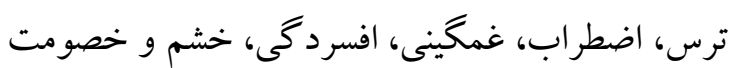
بخشى از سيستم رفتارى بازدارنده هستند كه هدف

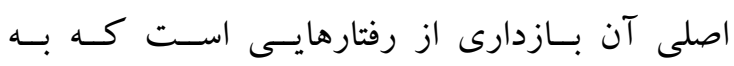

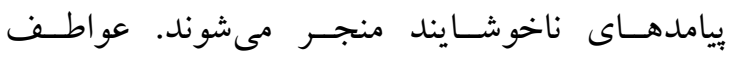
مثبـت شامل لـــت، علاقه، اعتمــاد و هشـيارى نيز بخشـى از سيسـتم رفتـارى تسهيلى هستند كه

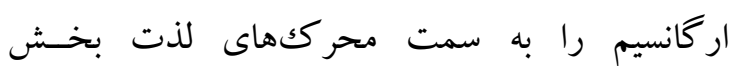
هدايـت مى كنند (باستان، يزدى و زهرايى، ههبr). يافتهاى يثزوهشى نشان مى دهند كه عاطفه منفـى بــا.

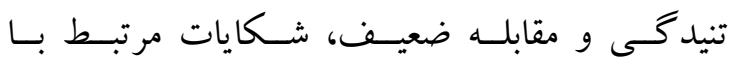
سلامت، فراوانسى رويدادهــاى ناخوشـــايند و عاطفــهـ مثبت با فعاليت و رضايت اجتماعى و نيز فراوانى رويدادهاى خوش آيند مرتبط مىباشند و نقش بسيار مهمسى در بهبـود افـراد از فشــار روانسى بــازى

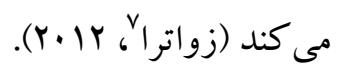
يكى ديخر از ويز گیىهاى افراد افسرده فقدان انعطاف بذيرى در زمينهاى مختلف است (عليزاده، حاجى يوسفى فقرورشى و ذوقى،

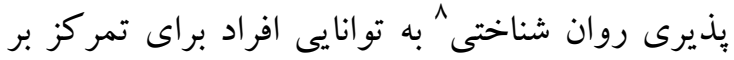

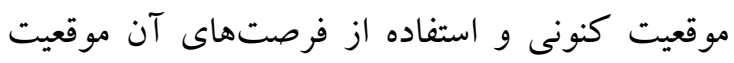
براى گام برداشتن در راستاى اهداف و ارزشهاى درونى با وجود حضور رويدادهاى روانشناختى جالش

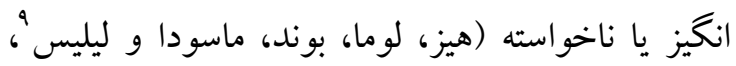

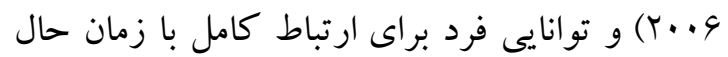
به عنوان يكك انسان هوشيار و توانايى او براى تغيير يا ادامه رفتار در جهت ارزشهايش تعريف شده است

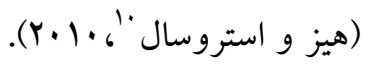

${ }^{7}$ Zautra

${ }^{8}$ Psychological flwxebility

${ }^{9}$ Hayes, Luoma, Bond, Masuda, Lillis

${ }^{10}$ Strosahl
مقدمه

افسردگ ' به عنوان يه يكى از شايعترين اختلالات ناتوان ساز و عود كننده (آريانا كيا، مرادى و حاتمى، سوسا؛ ويرسينگ، شمسالدين، گاربر، هولون، كلاركك و و

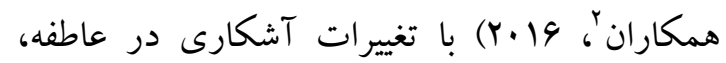
شناخت و كار كردهاى عصبى - زيستى كه در طى يك هـ دوره دو هفتهاى بروز مى كند و ضمن آن خلق افسرده يا بىعلاقكى و يا فقدان احساس لذت تقريباً در همه دوره كارها وجود دارد، مشخص مىشود (انجمن

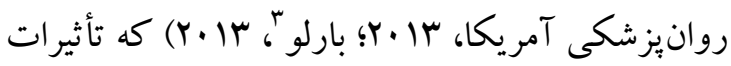
متعددى بر ابعاد مختلف زندگى دارد (عباس يور،

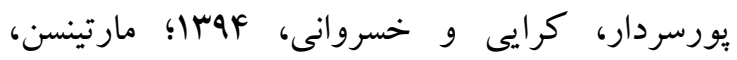

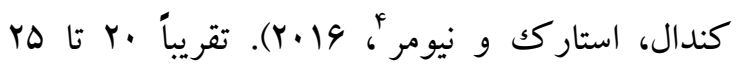
درصد زنان و · الى IV درصد مردان در طول عمرشان به اين اختلال مبتلا مىشوند (لوينسونه، و 9.ب).

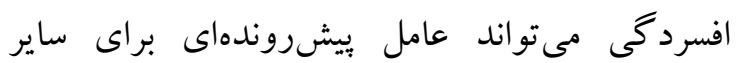

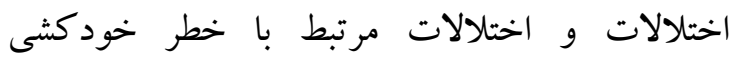

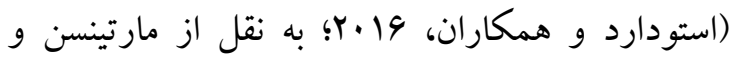
همكاران، (Y) 19)، مشكلات اجتماعى، وقايع منفى

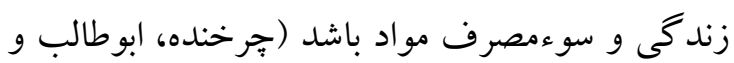

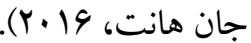
يكى از متغيرهـاى روانشناختى مرتبط با افسردگى هانى

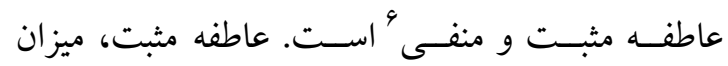
شور و شوق به زندگى و احساس هوشيارى فعاليت را در بر دارد و عاطفه منفى يكك بعد عام ناراحتى درونى وسى ونى

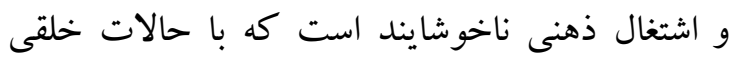

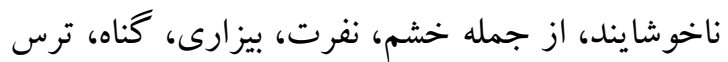
و عصبانيت همراه است (نريمانى، آريايوران،

\footnotetext{
depression

${ }^{2}$ Weersing, Shamseddeen, Garber, Hollon, Clarke, Beardslee et al

${ }^{3}$ Barlow

${ }^{4}$ Martinsen, Kendall, P. C., Stark, K., \& Neumer

${ }^{5}$ Levinson

${ }^{6}$ Positive and negative affect
} 
كه بيماران افسرده توانايى لذت بردن از زمان حال را ندارند و دركذشته يا آينده به سر مىبرند. به منظور كمكك به اين گونه بيماران مىتوان از درمانهاى مبتنى بر ذهن آكاهى استفاده نمود (اسمعيلى زاده آخوندى،

محمدعليز اده نمينى، لهوب().

شناخت درمانى مبتنى بر ذهن آكاهى (MBCT) از جمله درمانهاى موسوم به موج سوم رفتاردرمانى است كه در ابتدا به منظور بيشخيرى از عود افسردگى توسط

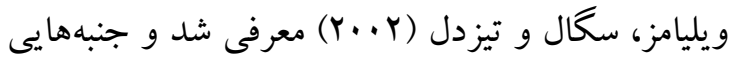
از شناخت درمانى را با تكنيكهاى مراقبه تركيب مى كند كه هدفش آموزش كنترل توجه به بيماران است تا بتواند تغييرات خلقى جزئى خود را شناسايى و از شروع مجدد بيمارى جلو گيرى كنند. شناخت درمانى مبتنى بر ذهن آكاهى مستلزم راهبردهاى رفتارى و شناختى و فراشناختى ويزه اى براى متمركز كردن فرايند توجه است كه به نوبه خود به جلو گيرى از عوامل ايجاد كننده خلق منفى، فكر منفى، گرايش به باسخهاى نكران كننده و رشد ديدكاه جديد و شكل گيرى افكار و هيجانهاى خوشايند منجر مى نورد

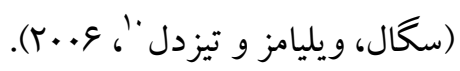

نتايج تحقيقات اثربخشى ذهن آكاهى بر بهبود خلق و و كاهش افسردگى (زيدان، جانسون، دياموند، ديويد،

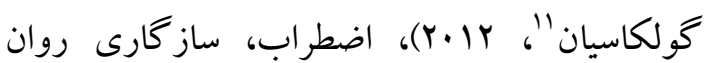
شناختى، استرس و عزت نفس (بوهلميجر، برنغر، تال

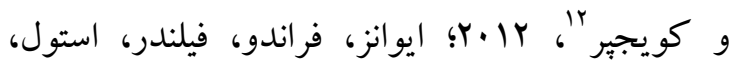

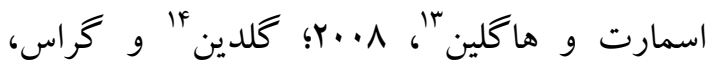

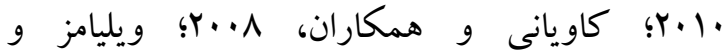

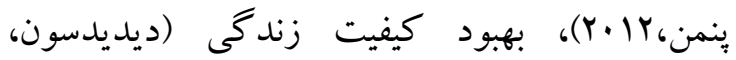

${ }^{10}$ Segal, Williams, Teasdale

${ }^{11}$ Zeidan, Johnson, Diamond, David, Goolkasian

${ }^{12}$ Bohlmeijer, Prenger, Taal, Cuijpers

${ }^{13}$ Evans, Ferrando, Findler, Stowell, Smart, Haglin

${ }^{14}$ Goldin, Gross
تحقيقات نشان دادهاند كه انعطاف يذيرى روانشناختى در فهم تنوع گستردهاى از مشكلات و علائم روانشناختى نقش بسزايى دارد (ايمانى، كريمى، بهبهانى و اميدى، هوس(1). رابطهى مثبت بين اجتناب تجربى/ انعطاف نايذيرى روانشناختى با دامنهاى

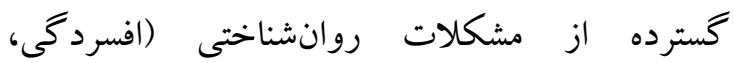
اضطراب، اضطراب اجتماعى، كذر هراسى، فوبى خون، اختلال موكنى، تنشهاى شغلى، سوء مصرف بـ

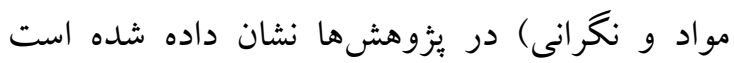
(فلدرز، بهلمجر و ييترز'، •l(Y).

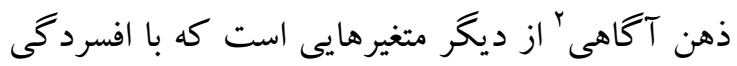

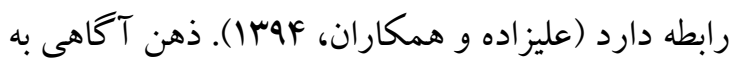
عنوان حالت توجه برانگيخته و آكاهى از آنجه كه در لحظهى كنونى اتفاق مىافتد تعريف شده است (والث،

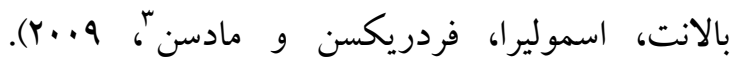
يثزوهش ها نشان دادهاند كه سطوح بالاتر ذهن آكاهى با سطوح بايين تر نشخوار فكرى، اجتناب، كمال گرايى و

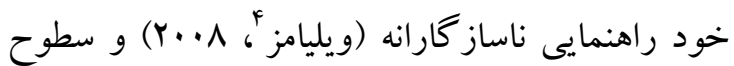
هايين ابعاد افسردگى و واضطراب رابطه دارد (دسروسيرز، كلمانسكى و نولن هكسما؛، با •r؟ وانگك،

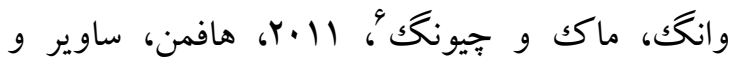

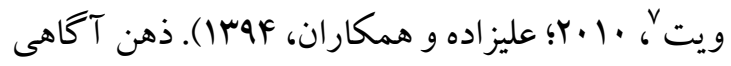
آگاهى باعث كيفيت زندگى بهتر، لذت بردن از زندگى و كاهش افسردگى و خشم مىشود (كيويت،

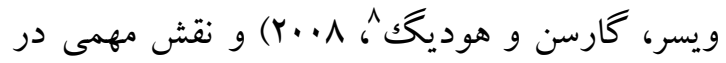
كاهش نشانهاى كوتاه مدت و درازمدت خلق افسرده

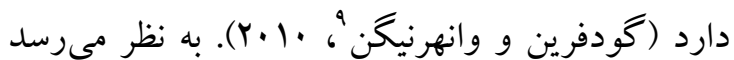

\footnotetext{
${ }^{1}$ Fledderus, Bohlmeijer, \& Pieterse

${ }^{2}$ Minfulness

${ }^{3}$ Walsh, Baliant, Smolira \& Madsen

${ }^{4}$ Williams

${ }^{5}$ Desrosiers, Klemanski, NolenHoeksema

${ }^{6}$ Wong, Mak, Cheung

${ }^{7}$ Hofmann, Sawyer, Witt

${ }^{8}$ Kieviet-Stijnen, Visser, Garssen, Hudig

${ }^{9}$ Godfrin, van Heeringen
} 
كنترل گمارده شدند. ملاككهاى ورود آزمودنىها به

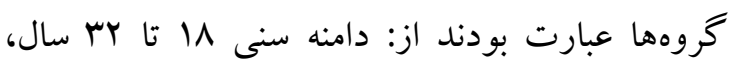

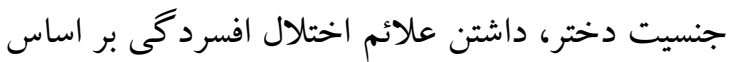
مصاحبه تشخيصى و مقياس افسردگى بكى، نداشتن

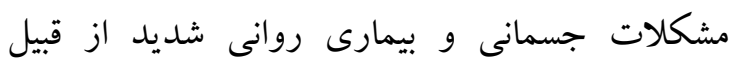
اختلالات شخصيت و اختلال تشخيص دادهشه بالينى بر اساس مصاحبه تشخيصى و عدم دريافت هر گونه مداخله دارويى و روانى ديخر حين انجام بيزوهش. ملاككهاى خروج از يثزوهش نيز عبارت بودند از: نقض

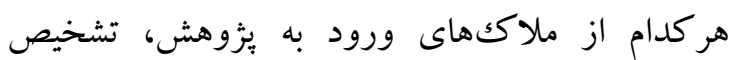
اختلال جسمانى يا روانى در حين اجراى يثزوهش، شركت نكردن در دو يا بيشتر از دو جلسه از جلسات درمان و نقص در تكميل برسشنامهها. بس از انتخاب و گمارش آزمودنىها و قبل از اجراى جلسات درمان

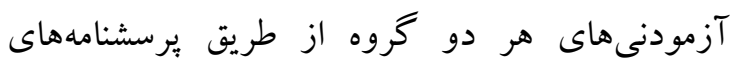
يذيرش و عمل - نسخه دوم (AAQ-II)، مقياس تجارب عاطفى مثبت و منفى اسيّن و برسشنامةُ بنج عاملى ذهن

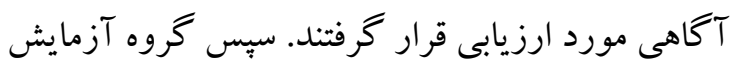
تحت مداخله 1 جلسهاى ذهن آكاهى مبتنى بر شناخت درمانى بر اساس جلسات هفتخى .9 دقيقهاى قرار كرفت و گرووه كنترل مداخلهاى دريافت نكرد. يس از يايان جلسات درمان آزمودنىهاى هر دو گروه مجدود مرداً با ابزارهاى بُزوهش مورد ارزيابى قرار كرفتند. دادههاى

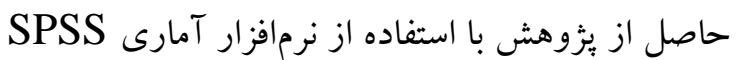
ويراست r Y و روش آمارى تحليل كواريانس مورد تجزيه و تحليل قرار گرفت. خلاصه اهداف و محتواى جلسات درمانى در زير آمده است. سطح معنادارى آمارى در كليه تحليل ها (ه •/>p) در نظر خرفته شد.
كابات زين، شاونجر، روزنكراس، مولر و سانترولى'؛

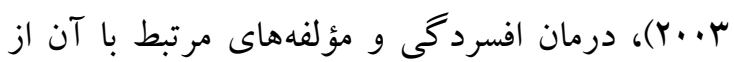
جمله خلق منفى، افكار خودآيند منفى، نكرشهاى ناكارآمد و افكار خودكشى (آذرگون، كجباف، مولوى و عابدى، צאז|) در افراد افسرده را نشان داده بر اساس بررسىهاى صورت كرفته توسط محقق،

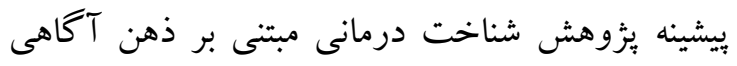

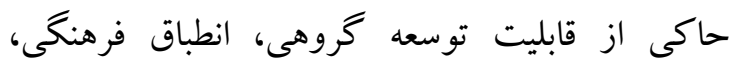
ماندگارى اثر نسبت به ساير روشها، مقرون به صرفه

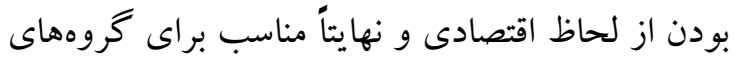
آسيب بذير است. از آنجا كه تاكنون يُزوهشى كه رويكرد ذهن آكاهى رادر حوزهى ارتقاى ابعاد مثبت الجن

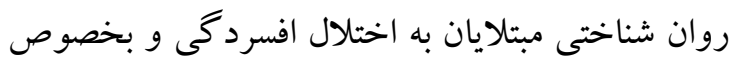
در حوزههاى عواطف مثبت و منفى، انعطاف يذيرى روان شناختى و مؤلفههاى ذهن آكاهى به كار كرفته باشد، انجام نشده است، يُوهش حاضر با هدف بررسى اثربخشى ذهن آكاهى مبتنى بر شناخت درمانى بر

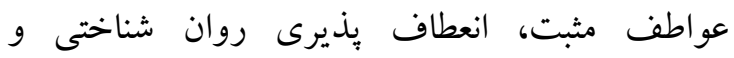
مؤلفههاى ذهن آكاهى دانشجويان داراى علائم اختلال افسردگى اساسى انجام شد.

روش بُزوهش نيمه تجربى همراه با گمارش تصادفى و

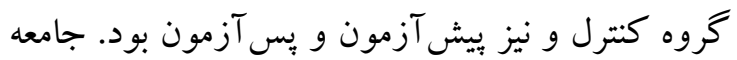

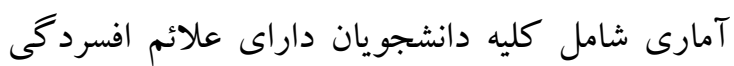
دانشگاه لرستان در سال تحصيلى نمونه شامل ·r نفر از دانشجويان دختر داراى علائم

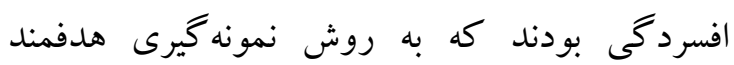

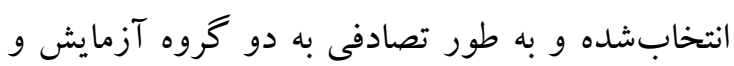




\section{جدول ا. خلاصدى محتواى جلسات شناخت درمانى مبتنى بر ذهن آكاهى ('MBCT)}

\begin{tabular}{|c|c|}
\hline اهداف و محتواى جلسات & جلسه \\
\hline 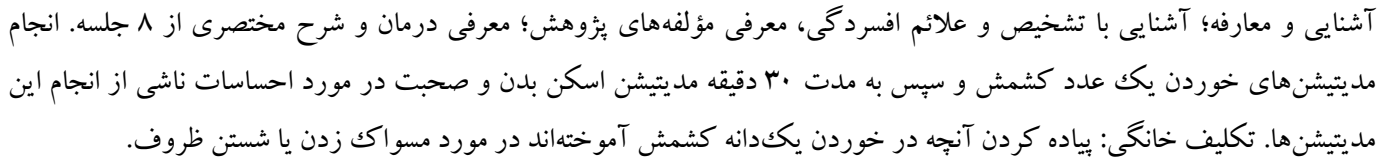 & 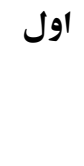 \\
\hline 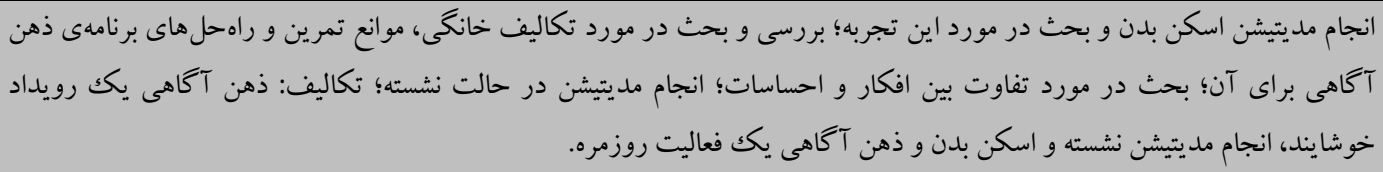 & دوم \\
\hline
\end{tabular}

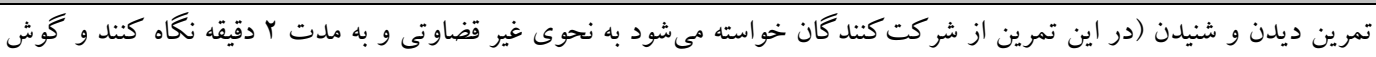

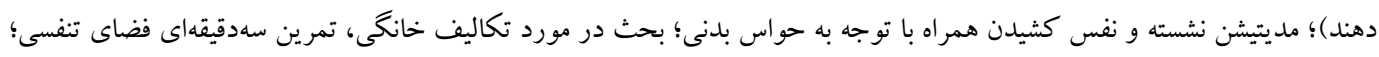

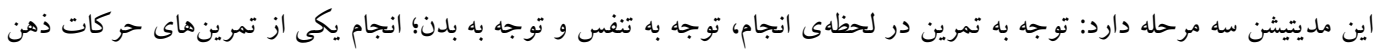

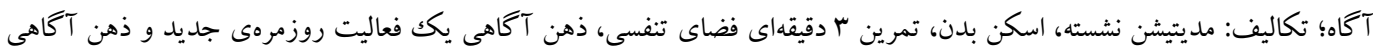

$$
\text { رويدادى ناخوشايند. }
$$

مديتيشن نشسته با توجه به تنفس، صداى بدن و افكار (كه مديتيشن نشسته جهاربعدى)؛ بحث در مورد باسخ هاى استرس و واكنش يكك

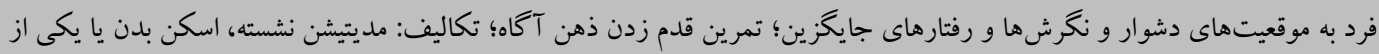

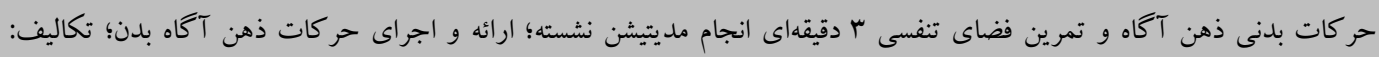

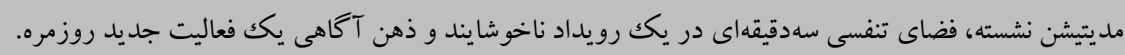

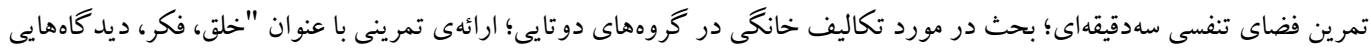

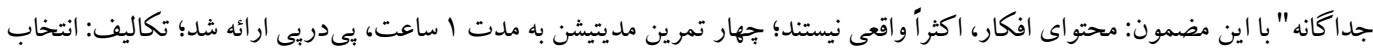

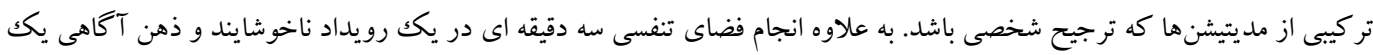

فعاليت جديد روزمره.

ششم مديتيشن جهاربعدى و آكاهى نسبت به هر آنجه در لحظه به هشيارى وارد مى شود؛ مضمون اين جلسه اين است: بهترين راه مراقبت از

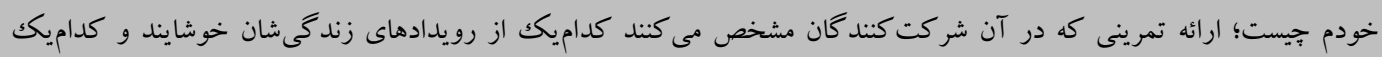

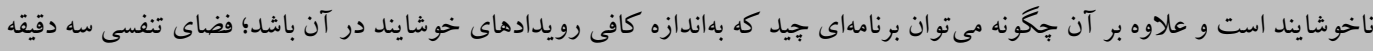

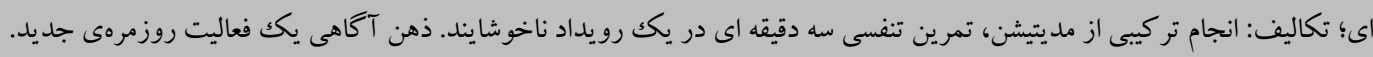

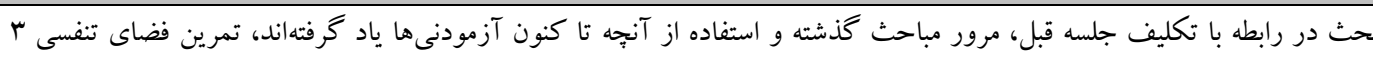

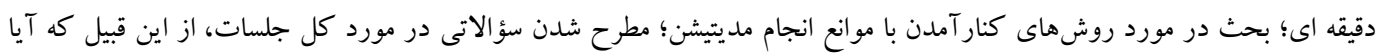

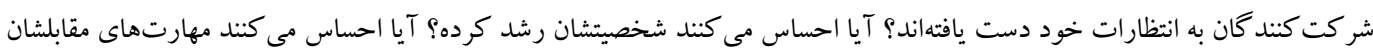

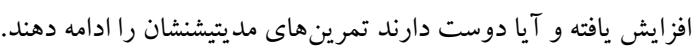




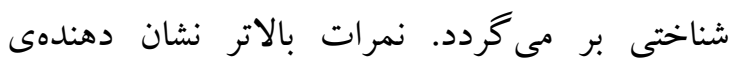

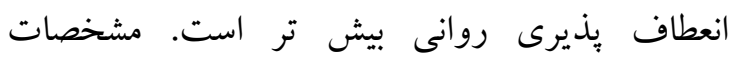
روانسنجى نسخه اصلى بدين شرح است: نتايج بركي شر كت كننده در طول 9 نمونه نشان داد كه اين ابزار يايايى، روايى و اعتبار سازهى رضايت بخشى دارد. ميانگين ضريب آلفا AF/ • و يايايى باز آزمايى در فاصله

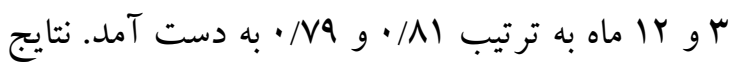
نشان داد كه برسش نامه يذيرش و عمل نسخه دوم به صورت همزمان، طولى و افزايشى دامنهاى از نتايج از سلامت ذهنى تا ميزان غيبت از كار را بيش بينى مى كند كه همسان با نظريهى زيربنايىاش است. اين ابزار همجنين اعتبار تمييزى مناسبى را نشان مىدهد (بوند و

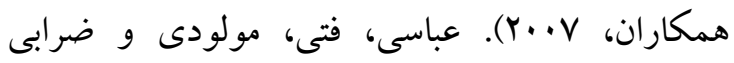

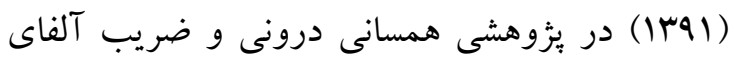

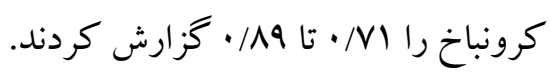
مقياس تجارب عاطفى مثبت و منفى اسيين" اين مقياس براى اولين بار توسط داينر، وايرتز، اويشى، بريتوهائه

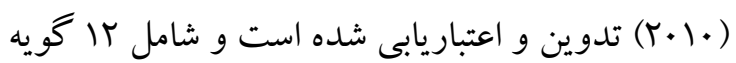

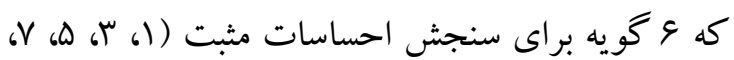

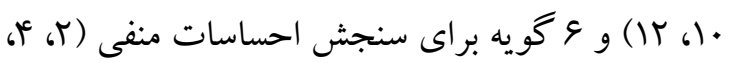

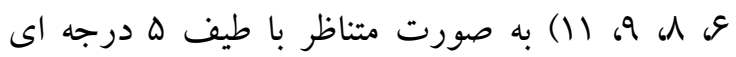

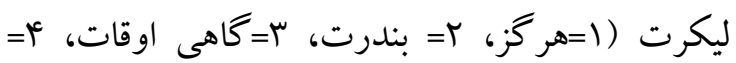

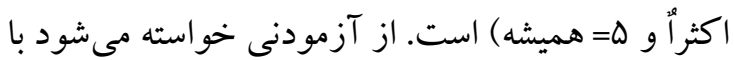
توجه به تجارب عاطفى خود در جهار هفته كذشته به

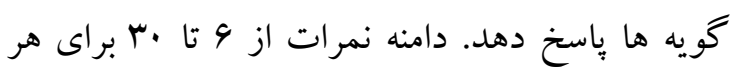
قسمت است يعنى هر فرد در اين مقياس دو نمره كسب تهب

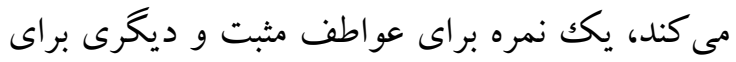

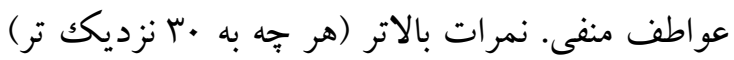
نشان دهنده تجربه بيشتر عواطف مثبت يا منفى در فرد

\footnotetext{
${ }^{4}$ Scale of Positive and Negative Experience (SPANE)
} ${ }^{5}$ Deiner, Wirtz. Tov, Oishi, Prieto سياهه افسردحى بك ويرايش دوم: برسشنامه افسردگى

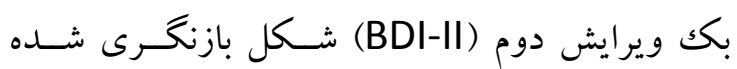

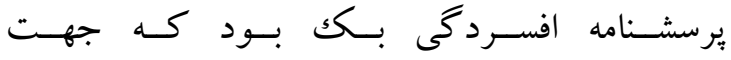

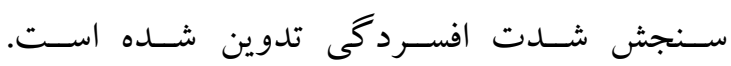

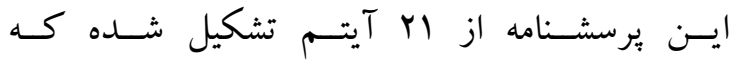

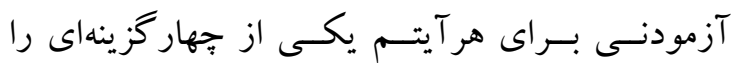

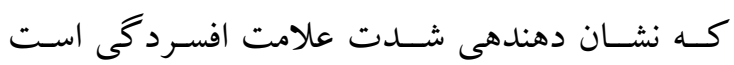

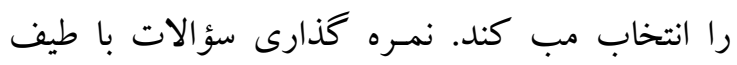
ليكرت و در دامنه صفر (فقدان افسردگى يا افسردگى خفيف) تا ب (افسردگى شديد) انجام مى شود و نمـره كل يرسشـنامه در دامنـه اى از صفرتـا بهو نوسان دارد.

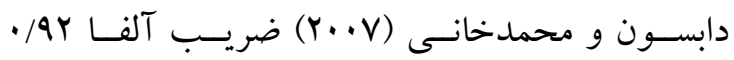

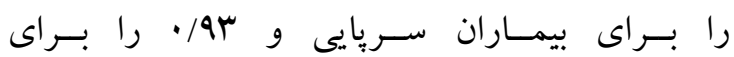

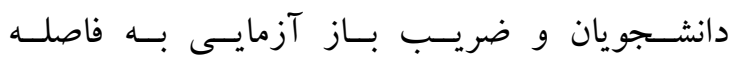

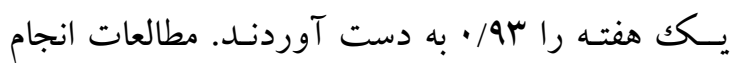

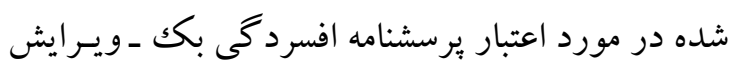
دوم (BDI-II) در كشورهاى مختلف نشان مىدهد كه اين يرسشنامه از اعتبار قابل قبولى برخـوردار اسـت.

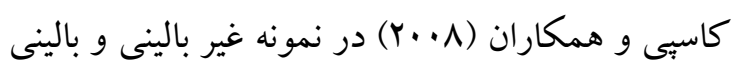

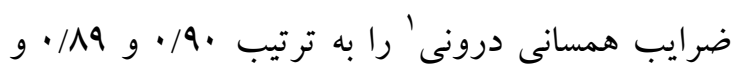
ضريب بازآزمايى ' را در نمونه غير بالينى

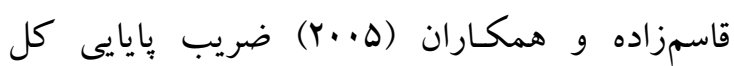

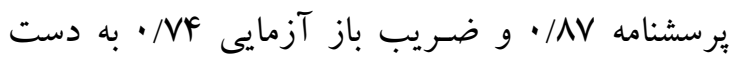
آوردند.

يرسشنامه بذيرش و عمل - نسخه دوم (AAQ-II): اين

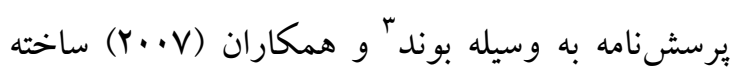

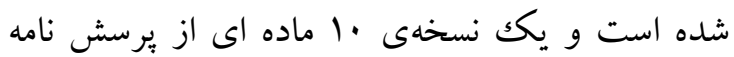
اصلى است (AAQ-I) كه به وسيله هيز (.... (Y) ساخته شده بود. اين برسشنامه سازه اي را مىسنجد كه به

\footnotetext{
${ }^{1}$ internal consistency

2 test-retest

${ }^{3}$ Bond
} 
QT)، سM). نمره گذارى برخى از مادهها در عوامل عدم

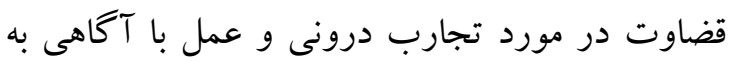
صورت معكوس است. ضريب آلفاى كرونباخ نمره

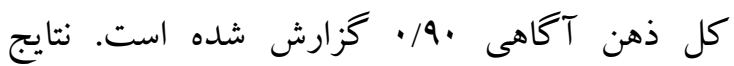
يزٔوهش احمدوند و همكاران (Yوسا) بيانكر اعتبار

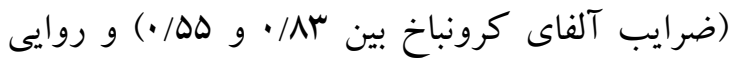

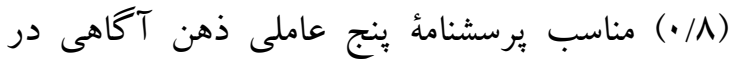
نمونه هاى غيربالينى ايرانى است. تمنايى فر و همكاران (IRAF)

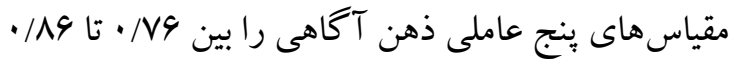
كز ارش كردند.

\section{يافتهها}

دامنه سنى مشار كت كنند كان در بثزوهش از 19 تا تا

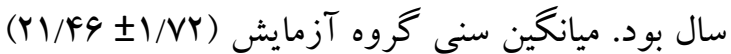

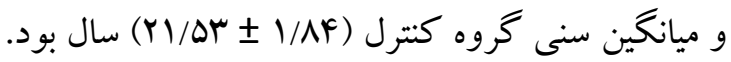
كليه افراد هر دو گروه آزمايش و كنترل مجرد بودند. از نظر تحصيلات بيشترين درصد آزمودنىها در هر دو گروه در حد تحصيلات كارشناسى بودند. در هر گروه تعداد دو نفر از آزمودنىها دانشجوى كارشناسى ارشد بودند. جدول Y يافته هاى توصيفى مؤلفه عواطف مثبت و منفى را برحسب عضويت گروهى و مراحل ارزيابى

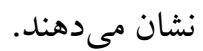

است. همرجنين اين مقياس قابليت نمره دهى به صورت تعادل ميان دو عاطفه مثبت و منفى را نيز دارد بدين صورت كه با تفريق نمره عواطف منفى از نمره عواطف مثبت محاسبه مىشود و نتيجه نمره تفاضل مى تواند بين ז متغير باشد. نمرات بالاتر و نزديك به ع ب نشان مىدهد كه فرد خيلى بندرت يا هر گز عواطف منفى را تجربه كرده است و اغلب يا هميشه عواطف مثبت را تجربه

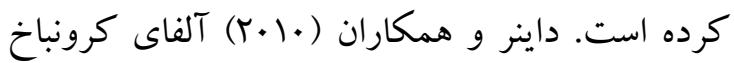
براى عواطف مثبت و منفى را به ترتيب AV/• و |NI/.

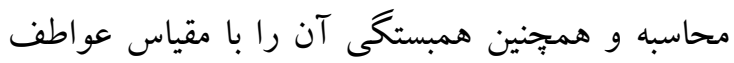
ياناس براى عواطف مثبت و منفى به ترتيب 191• و

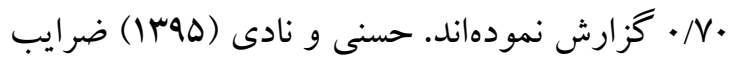
آلفاى كرونباخ اين برسش نامه را در يُزوهشى براى

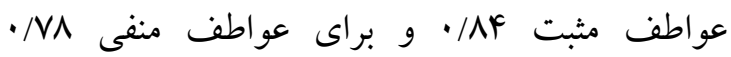
كزارش كردهاند. برسشامهُ ينج عاملى ذهن آتاهى (بائر و همكاران،

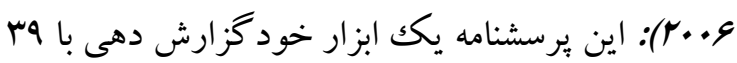
جمله است كه ينج عامل ذهن آكاهى را مىسنجد:

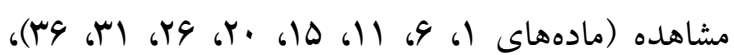

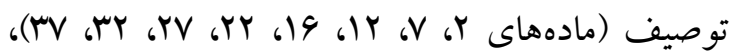

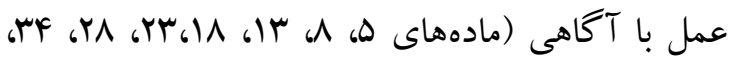
^r)، يذيرش بدون قضاوت در مورد تجارب درونى

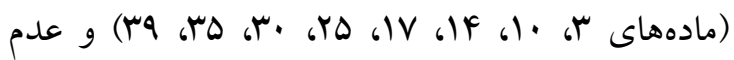

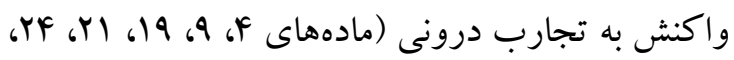

جدول r. يافته هاى توصيفى آزمودنىهاى يثوهش در عواطف مثبت و منفى و انعطاف يذيرى روان شناختى بر حسب عضويت كروهى و مراحل ارزيابى

\begin{tabular}{|c|c|c|c|}
\hline \multicolumn{2}{|c|}{ آزمايش كنترل } & مرحله & متغير \\
\hline ميانگين (انحراف استاندارد) & ميانگين (انحراف استاندارد) & & \\
\hline $10 / 49(F / 94)$ & $19 / 94(Y / V 9)$ & ييش آزمون & عاطفه مثبت \\
\hline $10 / Y r(r / Y r)$ & $r \cdot r / r(Y / r \Delta)$ & يس آزمون & \\
\hline$r \cdot / 9 \cdot(\Lambda / r \Lambda)$ & $r \cdot / F \cdot(r / \cdot 1)$ & بيش آزمون & عاطفه منفى \\
\hline
\end{tabular}




\begin{tabular}{|c|c|c|c|}
\hline $19 / Y \cdot(Y / 9 \Lambda)$ & $1 \Delta / \Gamma Y(Y / I Y)$ & يِ آزمون & \\
\hline$r Q / \Gamma Y(\Delta / A Y)$ & $r 9 / 99(9 / V F)$ & بيش آزمون & انعطاف يذيرى \\
\hline$r Q / V Y(G / r V)$ & $\mu \Delta(\Delta / \mu r)$ & يس آزمون & روانشناختى \\
\hline
\end{tabular}

است. جدول ץ يافتهاى توصيفى متغير ذهن آكاهى و

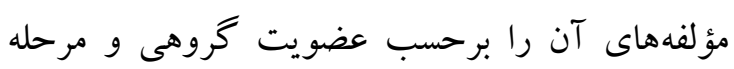
ارزيابى نشان مى دهند.
بر اساس نتايج جدول Y در هر دو مؤلفه عاطفه مثبت و

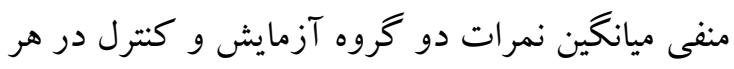

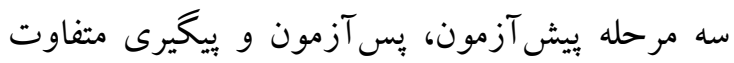

جدول ץ يافتهاى توصيفى آزمودنىهاى يؤهش در مؤلفه هاى ذهن آكاهى بر حسب عضويت تروهى و مراحل ارزيابى ميانكين (انحر اف استاندارد) ميانگين (انحر اف استاندارد)

\begin{tabular}{|c|c|c|c|}
\hline $19 / 9 \cdot(r / 94)$ & $19 / .9(F / 9 V)$ & يِيش آزمون & مشاهده \\
\hline $19 / 9 \cdot(r / 99)$ & $r \cdot / 9 r(r / \cdot r)$ & يس آزمون & \\
\hline $1 \Delta / \wedge \varphi(Y / N F)$ & $\mid r / \Delta r(F / \cdot \Lambda)$ & يِيش آزمون & توصيف \\
\hline $\mid Q / F \cdot(r / \mid 1)$ & $\operatorname{IV}(r / G F)$ & ي بس آزمون & \\
\hline $1 N / \cdot 9(F / F T)$ & NN/YG $(F / Y \cdot)$ & ييش آزمون & عمل همراه با آكاهى \\
\hline $1 \Lambda / q \Psi(F / V F)$ & $r \cdot(F / F V)$ & بس بَزمون & \\
\hline $1 \Delta / N T(F / V F)$ & $\mid F / \Lambda \cdot(F / G F)$ & ييش آزمون & عدم قضاوت \\
\hline $19 / 9 Y(F / F V)$ & $r \cdot / r \cdot(r / \backslash \Lambda)$ & ي بس آزمون & \\
\hline $1 N / \Delta r(Y / r q)$ & $1 V / .9(Y / F q)$ & ييش آزمون & عدم واكنش \\
\hline IN/FG (Y/IY) & $r \cdot / \Gamma(Y / 9 q)$ & يَ آزمون & \\
\hline
\end{tabular}

از سوى ديخر حجم دو گروه آزمايش و كنترل در اين يثزوهش مساوى با ها نفر بوده است كه حجمى مروه مساوى

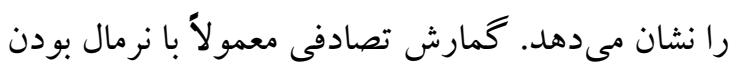
توزيع همراه است و نيازى به ارزيابى مستقل ندارد (مولوى، 9人א (1)؛ اما جهت حصول اطمينان از توضيح نرمال دادهها از آزمون شاييرو-ويلكز جهت بروسى نرمال بودن توضيح دادهها و آزمون لوين جهت تساوى

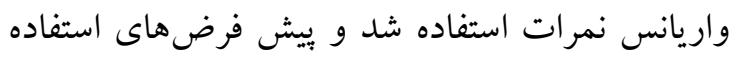
از تحليل كوواريانس تأييد كرديد. جدول F نتايج تحليل كواريانس جند متنغيرى را در رابطه با اثربخشى ذهن آكاهى مبتنى بر شناخت درمانى بر عواطف مثبت و منفى آزمودنى ها نشان مىدهد.
با توجه به نتايج جدول ب ميانگين نمرات مؤلفههاى ذهن آكاهى در گرووه آزمايش در مرحله يُ بس آزمون

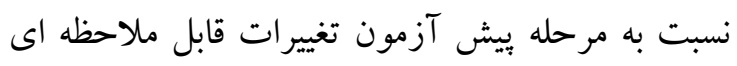
داشته است. جهت بررسى اين تفاوتها و ارزيابى دقيق تر نتايج درمانى از روش آمارى تحليل كورايانس

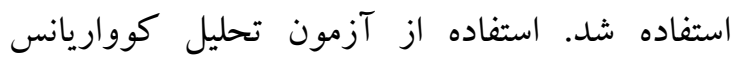
مستلزم رعايت مجموعه اى از ييش فرضها مى باشد.

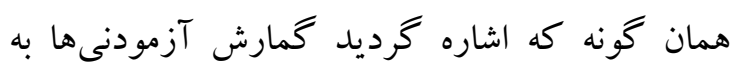
كروههاى يُزوهش به صورت تصادفى انجام شده است.

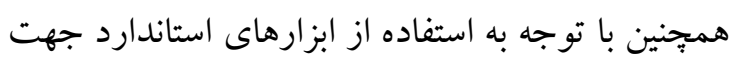
ارزيابى متغيرهاى وابسته، بيش فرض فاصله اى بودن مقياس اندازه گيرى متغيرهاى وابسته رعايت شده است. 


\begin{tabular}{|c|c|c|c|c|c|c|c|c|}
\hline توان آمارى & اندازه اثر & معنادارى & $\mathrm{F}$ & ميانيگين & Df & مجذورات & متغير وابسته & تغنيرات \\
\hline.$/ 99$. & $\cdot / 4 \Delta A$ & $\cdot / \cdots$ & $r \cdot / 1 \Delta r$ & IYV/VY. & 1 & ITV/VY. & عاطفه منفى & عضويت \\
\hline \multirow[t]{5}{*}{.$/ 991$} & .1011 & $\cdot \%$ & $r \Delta / / Y I$ & IFq/ArV & 1 & IFq/ArV & عاطفه مثبت & گروهى \\
\hline & & & & 9/M"s & YF & $1 \Delta r / \cdot V r$ & عاطفه منفى & خطا \\
\hline & & & & $\Delta / Q G F$ & YF & IFr/Irq & عاطفه مثبت & \\
\hline & & & & & $r$. & QYFF & عاطفه منفى & كل \\
\hline & & & & & $\mu$. & 9901 & عاطفه مثبت & \\
\hline
\end{tabular}

افسردگى شده است. در رابطه با مؤلفه عاطفه مثبت نيز اندازه اثر اهـ/ نشان مىدهد كه اه/ • از تفاوتها در متغير وابسته عاطفه مثبت در مرحله يس آزمون ناشى از عضويت گروهى است. به عبارتى ارائه مداخله ذهن آكاهى باعث افزايش اه درصدى عاطفه مثبت آزمودنى هاى بزّوهش شده است. توان آمارى نزديك به يكك هم حاكى از دقت آمارى بالا و كفايت حجم نمونه جهت ارزيابى فرضيه بزوهش است ( 0/05) جدول ه نتايج تحليل كواريانس تكك متنغيرى را در رابطه با اثربخشى ذهن آكاهى مبتنى بر شناخت درمانى بر انعطاف يذيرى روان شناختى آزمودنىها نشان

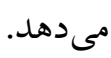

بر اساس يافتههاى جدول F) تفاوت معنى دارى بين كروه آزمايش و كنترل در نمرات بِ آزمون عاطفه مثبت و منفى مشاهده مىشود و افراد كروه آزمايش به نسبت نمرات بيش آزمون، ميانگين نمرات بيشترى در بس آزمون عاطفه مثبت و ميانگين نمرات كمترى در ״س آزمون عاطفه منفى كسب كردهاند. همجينين بين ميانگين كروه آزمايش و كنترل در هر دو مؤلفه در مرحله بِ بسزمون تفاوت معنىدارى وجود دارد. (p<0/05) تفاوتها در متغير وابسته عاطفه منفى در مرحله يس آزمون ناشى از عضويت گروهى است، به عبارتى مداخله شناخت درمانى مبتنى بر ذهن آكاهى باعث كاهش FD Pرصدى عاطفه منفى افراد داراى علائم

جدول ه. نتايج تحليل كواريانس تك متغيرى در رابطه با اثربخشى درمان مبتنى بر ذهن آكاهى بر

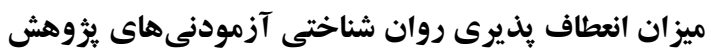

\begin{tabular}{|c|c|c|c|c|c|c|c|}
\hline توان & اندازه & معنادارى & $\mathbf{F}$ & ميانتين مجندورات & $D f$ & مجذوروات & تغييرات \\
\hline . MIr & $\cdot / Y 19$ & $.1 \cdot 10$ & $9 / 119$ & $r \cdot F / V q V$ & 1 & $r \cdot F / V q V$ & آزيش \\
\hline \multirow[t]{3}{*}{.199} & $\cdot / r \cdot V$ & $\cdot 1 \cdot 1 \mathrm{~V}$ & G/DYA & $19 F / \cdot V r$ & 1 & $19 F / \cdot V r$ & كروه \\
\hline & & & & rQ/VYV & ro & $V F \Psi / I A V$ & خطا \\
\hline & & & & & $r$. & rYG.r & كل \\
\hline
\end{tabular}

معنى دارى مشاهده مىشود. اندازه اثر V.Y. نشان مىدهد كه • ب/ • از تفاوتها در متغير وابسته انعطاف
با توجه به مندرجات جدول ه بين نمرات بس آزمون دو كروه در ميزان انعطاف يذيرى روان شناختى تفاوت 
كروه آزمايششده است (p>0/05). جدول 4 نتايج تحليل كواريانس جندم متغيرى را در رابطه با اثربخشى شناخت درمانى مبتنى بر ذهن آكاهى بر مؤلفهاى ذهن آكاهى آزمودنىهاى بزّوهش نشان مى بـدهد.
بذيرى روانشناختى در مرحله بس بـ آزمون ناشى از

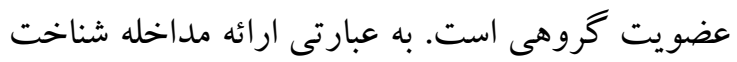

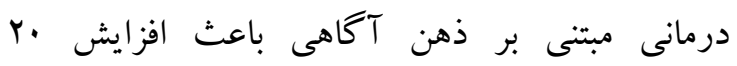

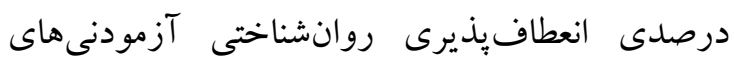

جدول 9 نتايج تحليل كواريانس جند متغيرى در رابطه با اثربخشى شناخت درمانى مبتنى بر ذهن آكاهى

\begin{tabular}{|c|c|c|c|c|c|c|c|}
\hline آمارى & اندازه اثر & معنادارى & $\mathbf{F}$ & مجذورات & Df & مجموع مجذورات & وابسته \\
\hline$\cdot 19 \cdot 4$ & $\cdot / r \cdot \Delta$ & $\cdot / r$. & $\Delta / F \| 11$ & $r q / q q$. & 1 & $\mu q / \mu q$. & مشاهده \\
\hline . /qra & . rar &.$/ . \cdot 1$ & $15 / 019$ & $k Y / F \cdot q$ & 1 & $F Y / F \cdot G$ & توصيف \\
\hline$\cdot / 499$ & $\cdot / \cdot 1 \Delta$ & $\cdot / \mathrm{WV}$ & $1 / 90$ & $r r / 949$ & 1 & $r r / 9 \times 9$ & همراه باه \\
\hline$\cdot 10 \cdot 9$ &.$/ 199$ &.$/ . \Delta 1$ & F/TA. & $\Delta F / 991$ & 1 & $\Delta F / 991$ & قضاوت \\
\hline.$/ 990$ & .1019 & $\cdot / \cdots$ & rY/rAD & $\triangle N / A T \Delta$ & 1 & $\triangle N / a T \Delta$ & واكنش \\
\hline
\end{tabular}

\section{بحث و نتيجه كيرى}

يزوهش حاضر با هدف بررسى اثر بخشى شناخت

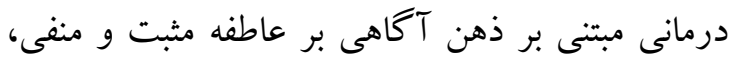

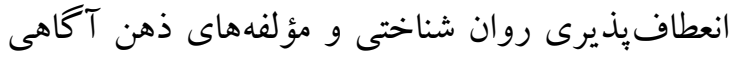
افراد داراى علائم افسردگى انجام شد. نتايج نشان داد كه آموزش ذهن آكاهى باعث افزايش معنىدار سطوح إنى عاطفه مثبت، انعطاف بذيرى روان شناختى و مؤلفهاى ذهن آكاهى و كاهش عاطفه منفى آزمودنىها شده است. نتايج اين يثوهش با نتايج بثزوهش هاى نريمانى و

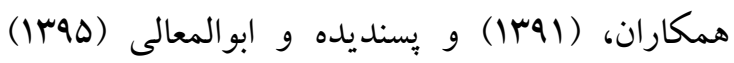

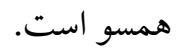
در تبيين اين يافته مىتوان كفت كه ذهن آكاهى، هشيارى غير قضاوتى و غير قابل توصيف و مبتنى بر زمان حال نسبت به تجربه اى است كه در يك لحظهى خاص در محدودهى توجه يكك فرد قرار دارد و علاوه
بر اساس نتايج جدول 9 تفاوت معنى دارى بين نمرات

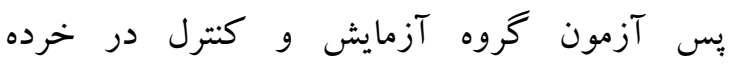
مقياسهاى مشاهده، توصيف، عدم قضاوت و عدم ترم واكنش وجود دارد. ميزان اندازه اثر نشان مىدهد كه به

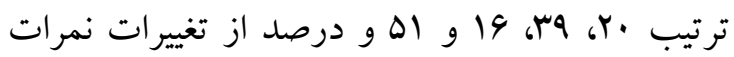
مؤلفههاى مشاهده، توصيف، عدم قضاوت و عدم واكنش در نتيجه عضويت گروهى است بهعبارتديخر

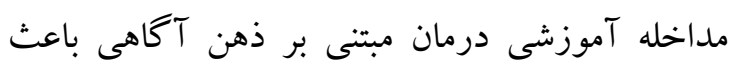
افزايش •r، وَ"، 19 و اله نمرات مؤلفههاى مشاهده، توصيف، عدم قضاوت و عدم واكنش در مرحله پِ آزمون در گروه آزمايش شده است. در رابطه با مؤلفه

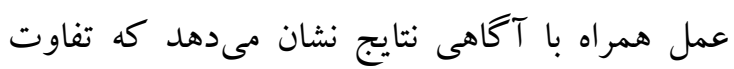

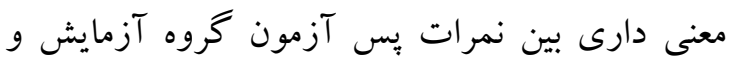
كنترل مشاهده نمى شود (p/05) 
كه افزايش توجه و آكاهى نسبت به افكار، هيجانات و تمايلات عملى از جنبههاى مثبت ذهن آكاهى است ولت استى (براون، ريان و كرسول، (Y.VV) و باعث هماهنگ

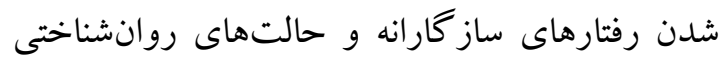
مثبت و موجب بهبود قابليت فردى در جهت فعاليتهاى انفرادى و اجتماعى و علاقه به اين

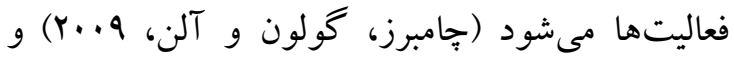
اين عوامل نيز به خودى خود مى توانند باعث كاهش علائم افسردگى و افزايش هيجانات ويز گحىهاى مثبت روان شناختى شوند. لذا آموزش ذهن آكاهى در افراد

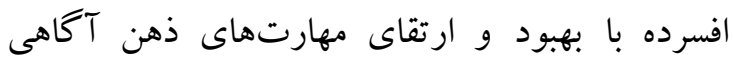
مىتواند در جهت افزايش عواطف مثبت آنان مؤثر باشد. عامل مشاهده در بر گيرنده توجه به محر ككهاى بيرونى و درونى مانند احساسات، شناخت ها، هيجانها، صداها و بوها است. توصيف به نام خذارى تجربههاى درونى

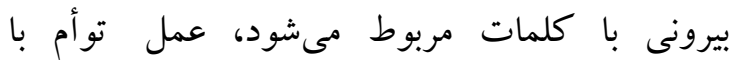
هو شيارى دربر گيرنده عمل كردن با حضور ذهن كامل

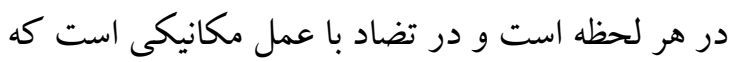
در هنگام وقوع ذهن فرد در جاى ديخرى است. غير قضاو تى بودن به تجربه درونى شامل حالت غير قضاوتى

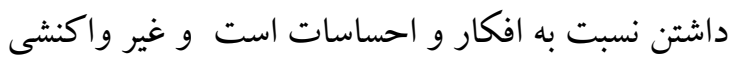
بودن به تجربه درونى اجازه آمد و رفت به افكار و احساسات درونى است بى آنكه فرد در آنها كير كند (براون، ريان و كراسول، V.·r). همه اين عوامل

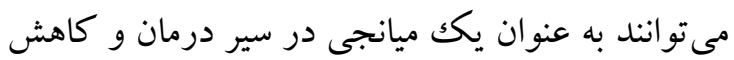
علائم منفى افسردگى كمك كنى كند و اثربخشى ذهن آكاهى در يزوهش حاضر مىتواند به واسطه افزايش ذهن آكاهى سطوح عاطفه مثبت و انعطاف يذيرى روان شناختى آزمودنى ها باشد. در اصل، آموزش ذهن آكاهى به افراد ياد مىدهد كه جُخونه مهارتهاى عادتى واقع در موتور مركزى' را از

${ }^{1}$ Central engine
بر آن، اين مفهوم اعتراف به تجربه ياد شده و يذيرش آن رانيز شامل مىشود و تأثير ذهن آكاهى در افزايش عاطفه مثبت، انعطاف بذيرى روان شناختى و مؤلفه هاى ذهن آكاهى و روان شناختى به فرد اين امكان را مىدهد تا به جاى آنكه به رويدادها به طور غير ارادى و بى تأمل بِاسخ دهد با تفكر و تأمل بِاسخ دهد و آنها را در شناخت، مديريت و حل مشكلات روزمره (زيدان و

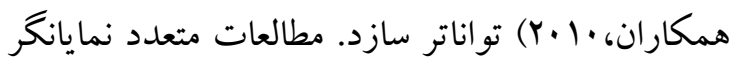
تأثير ذهن آكاهى افزايش يافته در بهزيستى روان شناختى زيرا درنتيجهى افزايش بهزيستى، اضطراب، افسردگى، عاطفهى منفى و نشانهاى روانشناختى كاهش يافته و عزت نفس، خوشينى و عاطفهى مثبت

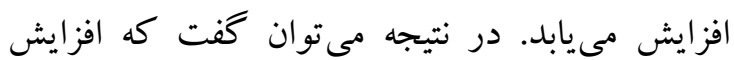
ذهن آكًاهى با كاهش نشانهاى منفى روانشناختى و عاطفهى منفى و در نتيجه افزايش عاطفه مثبت، انعطاف بذيرى روانشناختى و بهزيستى روانشناختى و هيجانى همراه است. آموزش ذهن آكاهى، با افزايش آكاهى افراد نسبت به حال، از طريق فنونى مثل توجه به تنفس و بدن و معطوف كردن آكاهى به اينجا و اكنون، بر نظام شناختى و بردازش اطلاعات تأثير مى گذارد و و و

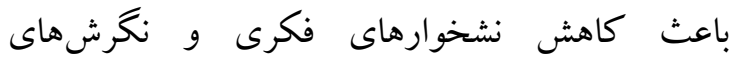
ناكارآمد در افراد مىشود. همجِنين افراد را متوجه افكار زائد خود مىسازد و مجدداً افكار آنها را به ساير جنبهاى زمان حال، نظير تنفس، راه رفتن همراه با حضور ذهن يا صداهاى محيطى، معطوف مىسازد و از اين طريق باعث افزايش عاطفه مثبت و كاهش عاطفه منفى مىشود.

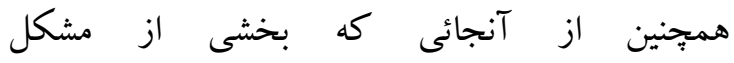
انعطافنايذيرى و عاطفه منفى افراد افسرده در عواملى بحسى المين جون عدم حضور ذهن آكاهانه در مكان و زمان نهفته است، لذا ارتقاء ذهن آكاهى گامى مهم در جلو گيرى از خود انتقادى و افزايش عاطفه مثبت است. به طورى 
جالش انگيز از جمله حالتها و موقعيتهاى هيجانى منفى، بدون واكنش به طور خود كار و عادت وار، طراحى شده است. افراد در نتيجه آموزش ذهن بهون

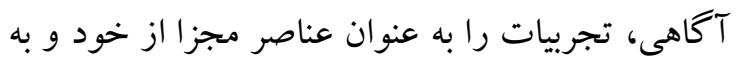
عنوان يك حالت گذراو به عنوان موضوعى براى تغيير مى يذيرند و لذا به جاى كاوش موضوع و يا اجتناب شناختى يا رفتارى از تجربه آن كه هر دو درد آور

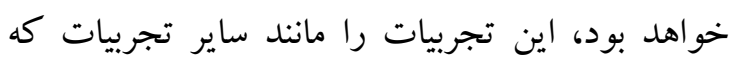
خنثى بوده و يا داراى بار هيجانى نمىباشند، يذيرفته و

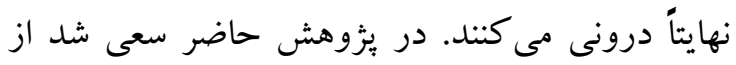

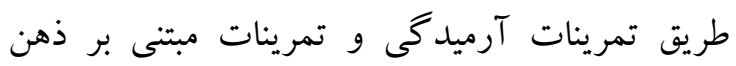

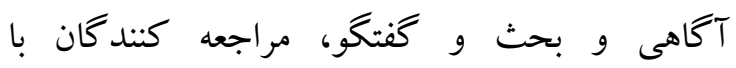
رويكردى غير قضاوت گرانه حالتهاى عاطفى و و هيجانى خود را مورد مشاهده قرار دهند و به آنها آموزش داده شد تا به جاى از مؤلفههاى شناختى، هيجانى و فيزيكى از تجربيات اجتناب كنند، اين

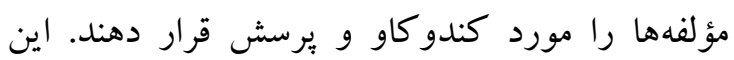

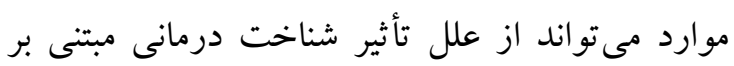

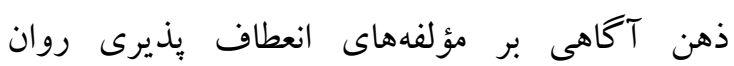

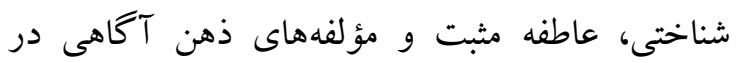
ئزوهش حاضر باشد.

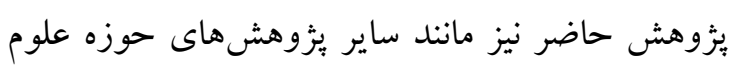
رفتارى داراى محدوديت هايى بود از جمله اينكه: نمونه يثزوهش حاضر صرفاً دختران داراى علائم افسردگى

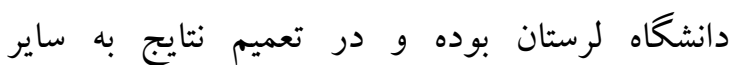
جمعيتهاى سنى و مردان و ساير نقاط بايد جوانب احتياط را رعايت نمود. از ديخر محدوديتهاى اين

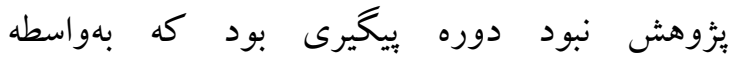

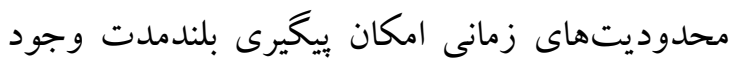
نداشت. در همين راستا و در راستاى نتايج بزوهش

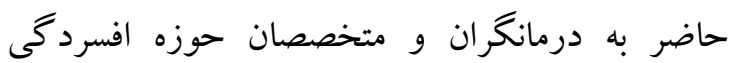
يشنهاد مى شود كه در بثزوهش هاى آتى بزّوهش حاضر
حالت تصلب خارج و با جهت دادن منابع بردازش اطلاعات به طرف اهداف خنثى توجه، مانند تنفس يا حس لحظه، شرايط را براى تغيير آماده كنند؛ بنابراين،

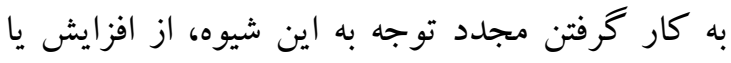

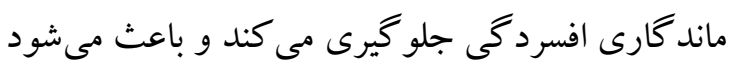
خرخههاى يردازش معيوب كمتر در دسترس قرار

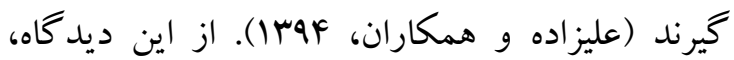
شانس گسترش يا سماجت افسردگى كاهش مى يابد. در اين شيوه، منابع حسى مانند الكوهاى معنايى است و

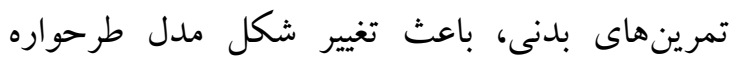

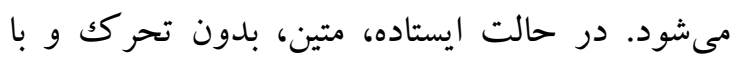

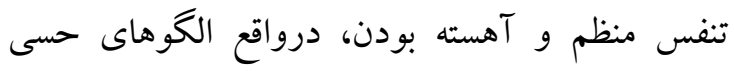

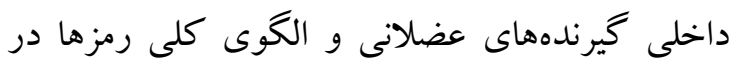
مدل ذهنى طرحوارهايى كه مربوط به موقعيت سخت است را تغيير مىدهند. در نتيجه، هنگامى كه در ذهن آكاهى، توجه را متمر كز مى كنيم، تغيير مدل طرحواره مشكل دار به اوج مىرسد و تصلب به وجود آمده

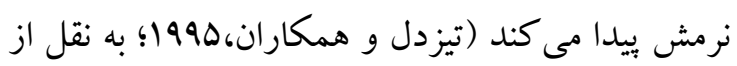

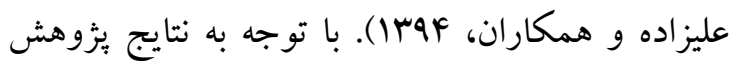
حاضر مىتوان اينگونه استباط كرد كه ذهن آكاهى موجب توقف خرخهى تجارب منفى درونى مانند

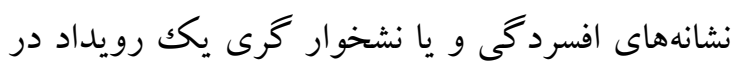

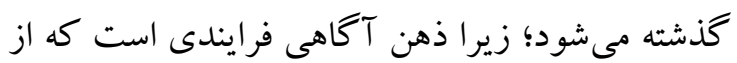
طريق آن فرد ثبات كاركردى خود را حفظ كرده و امكان انعطاف بذيرى در موقعيت هاى جديد را فراهم

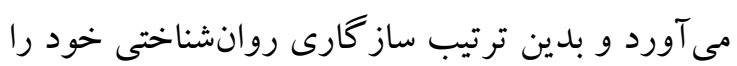

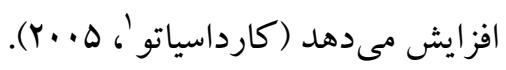
در شناخت درمانى مبتنى بر ذهن آكاهى، تمرينات و و تكنيككاى ذهن آكاهى به جهت كمكك به مراجعين

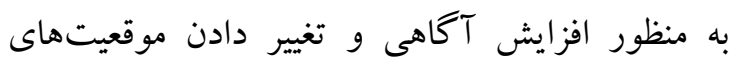

${ }^{1}$ Cardaciotto 
and acceptance Doctoral dissertation. University of Drexel, USA.

Charkhandeh, M., Abu Talib, M., \& Jane Hunt, C. (2016). The clinical effectiveness of cognitive behavior therapy and an altemative medicine approach in reducing symptoms of depression in adolescents. Psychiatry Research, http:/dx.doi.org/10.1016/j.psychres.2016.03.044.

Davidson, R. J., Kabat-zinn, J., Schumacher, J., Rosenkranz, M., Muller, D., Santorelli, S. F. (2003). Alterations in brain and immune function produced by mindfulness meditiation. Psychosomatic Medicine, 65: 564-570.

Desrosiers A, Klemanski DH, NolenHoeksema S. (2013). Mapping mindfulness facets onto dimensions of anxiety and depression. Behav Ther, 44: 373-84.

Evans S, Ferrando S, Findler M, Stowell C, Smart C, Haglin D. (2008). Mindfulness-based cognitive therapy for generalized anxiety disorder. J Anxiety Disord. (22): 716-721.

Gilbert P. (2007). Psychotherapy and counselling for depression. Third ed. London: SAGE Publications Ltd.

Gilbert, P. (2006). Evolution and depression: Issues and implications (invited review). Psychological Medicine, 36, 287-297.

Godfrin KA, van Heeringen C. (2010). The effects of mindfulness-based cognitive therapy on recurrence of depressive episodes, mental health and quality of life: A randomized controlled study. Behav Res Ther, 48(8): 738-46.

Goldin PR, Gross JJ (2010). Effects of mindfulnessbased stress reduction (MBSR) on emotion regulation in social anxiety disorder. Emotion. (10): 83-91.

Hatam Khani, S. (2011). The Relationship between Mindfulness Skills, Psychological Flexibility and Psychopathology Symptoms, Master's Degree Dissertation, General Psychology, Tarbiat Modares University, Faculty of Humanities. (In Persian).

Hayes, S. C., Luoma, J. B., Bond, F. W., Masuda, A., \& Lillis, J., (2006). Acceptance and commitment therapy: model, processes and outcomes. Behaviour Research and Therapy. 44: 1-25.

Hayes, S.C., Strosahl, K.D., Wilson, K.G., Bissett, R.T., Pistorello, J., Toarmino, D., Bergan, J. (2004). Measuring experiential avoidance: A preliminary test of a working model. The Psychological Record, 54(4), 553-578.

$$
\begin{aligned}
& \text { با تعداد نمونه بيشتر و بر روى جامعه مردان داراى علائم }
\end{aligned}
$$

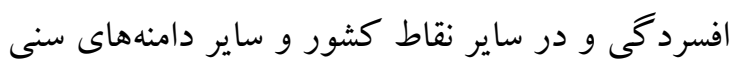

$$
\begin{aligned}
& \text { نيز اجرا كنند. همجنين به متخصصان اين حوزه بيشنهاد }
\end{aligned}
$$

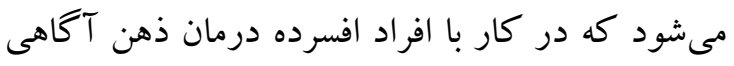

$$
\begin{aligned}
& \text { مبتنى بر شناخت درمانى را بهعنوان الكويى جهت } \\
& \text { افزايش عاطفه مثبت و كاهش عاطفه منفى، افزايش } \\
& \text { انعطاف يذيرى روانشناختى و مؤلفهاى ذهن آكاهى }
\end{aligned}
$$

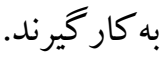

\section{Refrences}

Abbaspour, Z., Poursardar, F., Karayi, A, Khosravani Shayan, M. (2015). The Effectiveness of FamilyBased Interpersonal Psychotherapy on Depression Symptoms in Adolescents, Family Psychology, 2 (2): 67-78. (In Persian).

Alizadeh A, Yousefi E, Farvareshi M, Zoghi M. (2015). Predict symptoms of depression based on cognitive flexibility, rumination and mindfulness in students. Shenakht Journal of Psychology and Psychiatry, 2 (1):15-29. (In Persian).

American Psychiatric Association (2013). Diagnostic and statistical manual of mental disorders DSM-5 . Washington DC London, and England: Author.

Ariana-Kia, A.R, Moradi, M. Hatami. (2014). The Effectivness of Combined of Brief Behavioral Activation Therapy and Mindfulness-based Cognitive Therapy in Patients with Major Depressive Disorder. Joumal of Clinical Psychology, 6(1): 29-15. (In Persian).

Beyrami, M, Movahedi, Y, Alizadeh Gordal, J. (2015). Effectiveness of mindfulness therapy on cognition in reducing social anxiety and ineffective attitudes of adolescents, social cognition, 4 (1): 53-41. (In Persian).

Bohlmeijer E, Prenger R, Taal E, Cuijpers P. (2012). The effects of mindfulness-based stress reductiontherapy on mental health of adults with a chronic medical disease: A meta-analysis. J Psychosom Res. (68): 539-544.

Brown KW, Ryan RM. (2003). The benefits of being present: mindfulness and its role in psychological well-being. JPers Soc Psychol; 84(4):822-48.

Cardaciotto, LA. (2005). assessing mindfulness: The develop of a bi-dimensional measure of awareness 
Hayes, Steven C., Strosahl, Kirk D., \& Wilson, Kelly G. (2012). Acceptance and commitment therapy: the process and practice of mindfulchange. New York: Guilford Press.

Hofmann SG, Sawyer AT, Witt AA, et al. (2010). The effect of mindfulness-based therapy on anxiety and depression: A meta-analytic review. J Consult Clin Psychol; 78: 169.

Hosni, M, Nadi, M (2016). Psychometric properties of spin positive and negative emotional experiences scales in third grade high school students in Tehran, education and assessment, 9 (35): 124-105. (In Persian).

Imani M, Karimi J, Behbahani M, Omidi A. (2017). Role of mindfulness, psychological flexibility and integrative self-knowledge on psychological wellbeing among the university students. Feyz; 21 (2):170-177. (In Persian).

Kashdan, TB. Rottenberg, J. (2010). Psychological flexibility as a fundamental aspect of health. Clin Psych Rev, 30, 865-78.

Kaviani, H, Hatami, N., \& Shafie abadi, A. (2008). The Effectiveness of Cognitive therapy based on Minfulness in quality of life of depressed people. New cognitive sciences. 4, 10: 39-48. (In Persian).

Kaviani, H,. Javaheri, F,. Bahriani, H. (2004). Effective cognitive therapy based on mind-consciousness in reducing their negative thoughts, ineffective attitude, depression and anxiety, 60-day follow-up, Journal of Cognitive Science, vol. 7, No. 1, 49-59. (In Persian).

Kieviet-Stijnen A, Visser A, Garssen B, Hudig W. (2008). Mindfulness-based stress reduction training for oncology patients: patients' appraisal and changes in well-being. Patient Educ Couns.; 72(3):436-42.

Levinson, DF. (2006). the genetics of depression: A review. Biological Psychiatry, (60), 84-92.

Martinsen, K. D., Kendall, P. C., Stark, K., \& Neumer, S. P. (2016). Prevention of anxiety and depression in children: Acceptability and feasibility of the Trans diagnostic EMOTION program. Cognitive and Behavioral Practice, 23, 1-13.

Mohammadalizadeh Namini A, Esmaeilzadeh Akhoundi M. (2016). Comparing the components of mindfulness and emotional health in people with major depression, generalized anxiety disorder and normal individuals. Shenakht Journal of Psychology and Psychiatry; 3 (4):12-26. (In Persian).

Narimani, M., Aryapouran,. S, Abolghasemi, S Ahadi, B. (2012). Effectiveness of mindfulness-based stress reduction and emotion regulation training in the affect and mood of chemical weapons victims, Arak Medical University Joumal (AMUJ). 15(61): 107118. (In Persian).

Pasandideh, R. Abu al-Ma'ali, KH (2016). Effectiveness of cognitive therapy based on mind-awareness on increasing well-being, thought and behavior, 11 (41): 18-7. (In Persian).

Pennant, M. E., Loucas, C. E., Whittington, C., Creswell, C., Fonagy, P., Fuggle, P., et al. (2015). Computerized therapies for anxiety and depression in children and young people: A systematic review and meta-analysis. Behavior Research and Therapy, 67, 1-18

Rustaie, M. (2014). The Effectiveness of MindfulnessBased Stress Management Training on Depression, Anxiety and Depression in Girl Students, Thought and Behavior, 9 (37): 48-37. (In Persian).

Segal ZV., Williams J.M.G., Teasdale J.D. (2002). Mindfulness-based cognitive therapy for depression - a new approach to preventing relapse. Guilford Press; New York.

Sharifibastan F, Yazdi S, zahraei S. (2016). The Role of Cognitive Emotion Regulation and Positive and Negative Affect in Resiliency of Women with Breast Cancer. Iranian Joumal of Psychiatric Nursing (IJPN); 4(2):38-49. (In Persian).

Tamanaiefar, Sh,.Asghamejad; A.. Mirzai; M, Soleimani, M. (2016). Psychometric Properties of the Five Factors of Mindfulness Knowledge, Developmental Psychology, 12 (47): 330-321. (In Persian).

Walsh, J., Baliant, MG. Smolira, SJDR. Fredericksen, LK. \& Madsen, S. (2009). Predicting individual

Differences in mindfulness: The role of trait anxiety, attachment anxiety and attentional control, Personality and Individual differences, 46, 9499.

Weersing, V. R., Shamseddeen, W., Garber, J., Hollon, S. D., Clarke, G. N., Beardslee, W. R., et al. (2016). Prevention of depression in at-risk adolescents: Predictors and moderators of acute effects. Joumal of the American Academy of Child \& Adolescent Psychiatry, 55, 219-226.

Williams JM. (2008). Mindfulness, depression and modes of mind. Cogn Ther Res; 32: 721- 33.

Wong SY, Mak WW, Cheung EY, et al. (2011). A randomized, controlled clinical trial: The effect of mindfulness-based cognitive therapy on generalized anxiety disorder among Chinese community patients: protocol for a randomized trial. BMC Psychiatry; 11: 187. 
Zautra AJ, Hall JS, (2002). Editors. Handbook of Adult Resilience: Guilford Publications; 2012. 38. Fredrickson BL, Joiner T. Positive emotions trigger upward spirals toward emotional well-being. Psychol Sci.13(2):172-5.

Zeidan F, Johnson SK, Diamond BJ, David Z, Goolkasian P. (2012). Mindfulness meditation improvescognition: Evidence of brief mental training. Conscious Cogn. (19): 597-605. 